\title{
Multidrug-Resistant Tuberculosis in Children: A Single-Center Experience
}

\author{
Çocuklarda Çok Ilaca Dirençli Tüberküloz: Tek Merkez Deneyimi
}

\author{
Deniz Aygün'(iD), Tarık Yıldırım²(ID), Özlem Başoğlu Öner²(iD), Sezer Toprak³(iD), Aylin Babalık(iD), Zeki Kılıçaslan(iD), \\ Rengin Şiraneci ${ }^{1}(\mathrm{ID})$ \\ ${ }^{1}$ Division of Pediatric Infectious Diseases, Clinic of Pediatrics, Istanbul Kanuni Sultan Süleyman Training and Research Hospital, Istanbul, Turkey \\ ${ }^{2}$ Clinic of Pediatrics, Istanbul Kanuni Sultan Süleyman Training and Research Hospital, Istanbul, Turkey \\ ${ }^{3}$ Clinic of Microbiology and Clinical Microbiology, Istanbul Süreyyapaşa Chest Diseases and Chest Surgery Training and Research Hospital, Istanbul, Turkey \\ ${ }^{4}$ Clinic of Chest Diseases, İstanbul Süreyyapaşa Chest Diseases and Chest Surgery Training and Research Hospital, Istanbul, Turkey \\ ${ }^{5}$ Departmenf of Chest Diseases, Istanbul University Çapa School of Medicine, Istanbul, Turkey
}

Cite this article as: Aygün D, Yıldıım T, Başoğlu Öner Ö, Toprak S, Babalık A, Kılıçaslan Z, et al. Multidrug-resistant tuberculosis in children: a single-center experience. J Pediatr Inf 2020;14(4):e188-e194.

\section{Abstract}

Objective: Resistance to at least isoniazid and rifampicin, which are the most important drugs in TB treatment, is called multidrug-resistant tuberculosis (MDR-TB). MDR-TB is a life-threatening condition that affects children as well as adults.

Material and Methods: The medical records of children diagnosed with MDR-TB between June 2015 and October 2018 were analyzed retrospectively.

Results: Seven female (77.8\%) and two male (22.2\%) patients were included into the study. Their mean age was $11.58 \pm 4.23$ years (3.75-15 years). Five patients (55.5\%) had family members with MDR-TB. All of them had pulmonary tuberculosis. Acid-resistant bacteria (ARB) were observed in three (33.3\%) patients, nucleic acid amplification tests were positive in four (44.4\%) patients, and positive cultures were observed in seven (77.7\%) patients. Seven patients had microbiologically and two patients had clinically confirmed MDR-TB. Five patients (55.5\%) had isoniazid and rifampicin resistance, two patients (22.2\%) had isoniazid, rifampicin and streptomycin resistance. A treatment protocol consisting of pyrazinamide, ethambutol, amikacin, protionamide and moxifloxacin was started after evaluating the culture results of the patients and family members. Cycloserine was added to the treatment protocol of four (44.4\%) patients. The total treatment process was continued for 18 months.

Conclusion: Management of childhood MDR-TB is a long and difficult process, but it is a preventable and treatable disease.

Keywords: Children, diagnosis, multidrug resistant tuberculosis, treatment
Öz

Giriş: Tüberküloz (TB) tedavisinde en önemli ilaçlar olan izoniyazid ve rifampisine direnç çok ilaca dirençli tüberküloz (ÇiD-TB) olarak tanımlanmaktadır. Çok ilaca dirençli tüberküloz erişkinler kadar çocukları da etkileyen hayatı tehdit eden bir durumdur.

Gereç ve Yöntemler: Haziran 2015-Ekim 2018 tarihleri arasında ÇiD-TB tanısı alan çocukların tıbbi kayıtları geriye dönük olarak incelendi.

Bulgular: Yedi kız (\%77.8) ve iki erkek hasta (\%22.2) çalışmaya dahil edildi. Hastaların ortalama yaşları $11.58 \pm 4.23$ yıldı (3.75-15 yıl). Beş hastanın (55.5\%) ailesinde ÇiD-TB tanılı bir aile üyesi vardı. Hastaların hepsi akciğer tüberkülozu tanılıydı. Aside dirençli basil (ARB) pozitifliği üç hastada (\%33.3), nükleik asit amplifikasyon testi pozitifliği dört hastada (\%44.4), kültür pozitifliği yedi hastada (\%77.7) gözlendi. Yedi hastada mikrobiyolojik, iki hastada klinik olarak ÇiD-TB saptandı. Beş hastada (\%55.5) izoniyazid ve rifampisin direnci, iki hastada (\%22.2) izoniyazid, rifampisin ve streptomisin direnci vardı. Hastaların ve aile üyelerinin kültür sonuçlarını değerlendirdikten sonra pirazinamid, etambutol, amikasin, protionamid ve moksifloksasinden oluşan tedavi protokolü başlandı. Sikloserin dört hastanın (\%44.4) tedavisine eklendi. Toplam tedavi süresi 18 ay devam edildi.

Sonuç: Çocukluk çağı ÇiD-TB'nin yönetimi uzun ve zor bir süreç olmakla birlikte önlenebilen ve tedavi edilebilen bir hastalıktır.

Anahtar Kelimeler: Çocuklar, çok ilaca dirençli tüberküloz, tanı, tedavi

Correspondence Address/Yazışma Adresi

Deniz Aygün

İstanbul Kanuni Sultan Süleyman

Eğitim ve Araştırma Hastanesi,

Çocuk Sağlığı ve Hastalıkları Kliniği,

İstanbul-Türkiye

E-mail: fdenizaygun@gmail.com 


\section{Introduction}

Tuberculosis (TB) is a grave global public health problem and a leading cause of death among infectious diseases despite control strategies. In 2017, the World Health Organization (WHO) reported an estimated 10.0 million TB cases, 1 million of which were children (1). Childhood TB is a difficult disease to treat due to lack of standard clinical and radiological description. Bacteriological confirmation is also low in children because of technical difficulties in sampling and the paucibacillary nature of the disease (2-4).

One of the most important factors affecting the treatment of tuberculosis is drug resistance (5). Resistance to at least isoniazid and rifampicin, which are the most important agents in TB treatment, is called multidrug-resistant tuberculosis (MDRTB). A global total of 186.772 cases of MDR-TB were detected in 2018 with a treatment success rate of 56\% (6). MDR-TB is a life-threatening condition that affects children as well as adults. Globally, it is estimated that 32.000 children younger than the age of 15 develop MDR-TB each year, but most are not diagnosed, probably due to problems in recordkeeping $(5,7)$. The diagnosis of MDR-TB is time-consuming, requiring microbiological confirmation and drug-susceptibility tests (DST) that usually take longer than four weeks.

There is also little information about the optimal treatment of MDR-TB, which is a complex, long, and costly process. The use of second-line medications, lack of child-friendly formulations, treatment abandonment problems, and possible drug side effects are the main handicaps (8-10). On the other hand, the outcome of MDR-TB treatment in children is generally effective in cases of early diagnosis and treatment. There are relatively few pediatric reports in the literature about MDR-TB. This study aimed to elucidate our clinical experience in the diagnosis and successful treatment of nine children with MDRTB from a single center.

\section{Materials and Methods}

\section{Study Design}

This retrospective single-center study enrolled patients at Kanuni Sultan Süleyman Research and Training Hospital, Department of Pediatric Infectious Disease, between June 2015 and October 2018. We analyzed the detailed data of 200 patients diagnosed with TB.

The medical records of all patients were reviewed to obtain data on patient age, sex, contact history, the culture results and drug susceptibility of the contact case, tuberculin skin test (TST) results, laboratory and radiological findings, ARB, Mycobacterium tuberculosis (MTB) polymerase chain reaction positivity, MTB culture, resistance results, treatment, and complications.

\section{Patient Definitions}

MDR-TB diagnosis was based on history of exposure to index case; positive TST, clinical, and radiological findings; and microbiological results. Patients were diagnosed with MDR-TB when nucleic acid amplification tests and/or bacteriological cultures confirmed multi-drug resistance with DSTs from adequate samples.

In the absence of microbiological confirmation, patients were considered to have probable or presumed MDR-TB if they had a known contact with an infectious adult with MDRTB and/or signs or symptoms of TB and/or immunological evidence of M. tuberculosis with positive TST.

The posterior-anterior chest radiographs and/or thoracic computerized tomography findings of all patients with pulmonary tuberculosis (PTB) were evaluated for hilar or mediastinal lymphadenopathy, consolidation, atelectasis, and pleural effusions.

\section{Laboratory Investigations}

A standard TST was performed placing purified protein derivative (PPD) $(0.1 \mathrm{~mL}$ containing 5 Todd units) intradermally and reading the results after $48-72$ hours. In children vaccinated with $B C G$, an induration of $\geq 15 \mathrm{~mm}$ was considered a positive reaction.

Clinical samples including sputum or gastric aspirate were examined by Ziehl-Neelsen acid-fast staining. The Kinyoun set staining method was used to detect ARB. Lowenstein-Jensen solid medium and BACTEC ${ }^{\text {TM }}$ MGIT ${ }^{\text {TM }} 960$ System liquid broth medium were used for the cultivation and isolation of Mycobacterium species.

First, in positive culture samples, the differentiation of nontuberculous mycobacteria was examined by immunochromatographic assay (BD MGIT TBc identification test). Susceptibility to isoniazid, rifampicin, streptomycin, and ethambutol was detected by BD BACTEC MGIT 960 SIRE culture kits.

The Seegene Anyplex MTB/NTM Real-Time Detection Assay demonstrated the differentiation of nontuberculous mycobacteria. For MTB-positive samples, four mutations for isoniazid KatG, three mutations for inhA promoter, and 18 mutations for rifampicin rpoB genes were analyzed. The Anyplex II MTB/MDR and MTB/XDR Detection (Seegene, Korea) analysis system was used to identify MDR-TB and extensively drug-resistance tuberculosis.

\section{Statistical Analysis}

IBM SPSS Statistics for Windows version 21.0 (IBM Corp.) was used for statistical analysis. Numerical data were expressed as mean \pm standard deviation and categorical data were expressed as frequency ( $\mathrm{n}$ ) and percentage (\%). Approval was obtained from the Local Ethics Committee to perform 
our study (2019.05.128). A signed informed consent form was obtained from all parents of the patients in this study.

\section{Results}

\section{Demographic Data}

We analyzed the detailed data of 200 patients diagnosed with TB, $21.3 \%$ of them had acid-resistant bacteria (ARB) and $19.4 \%$ of them had M. tuberculosis culture positivity.

Nine patients were diagnosed as MDR-TB, seven of whom were females $(77.8 \%)$ and two of whom were males (22.2\%). Their mean age was $11.58 \pm 4.23$ years (3.75-15 years). Five patients $(55.5 \%)$ had family members with microbiologically confirmed MDR-TB. The family members were properly on treatment protocol of MDR-TB. All of the patients were of Turkish origin and had received the Bacille Calmette-Guérin vaccine. All of the patients had low socioeconomic status and the body weights of all patients were below the third percentile. None of the patients had a comorbid disease.

\section{Clinical and Laboratory Findings}

All of the patients were symptomatic, prolonged cough was the most common symptom present in all patients, followed by sputum production ( $n=6,66.6 \%)$, weight loss and night sweating $(n=4,44.4 \%)$, and fever $(n=2,22.2 \%)$. The patients were diagnosed with pulmonary TB. All patients were negative for HIV. Mean vitamin $D$ level of the patients was $10.01 \pm 4.13 \mathrm{ng} / \mathrm{mL}$. Tuberculin skin test was positive in five of patients (55.5\%).

All of the patients had radiologic findings on chest X-rays either mediastinal or hilar lymphadenopathy, lober or patchy consolidation and air bronchogram. Cavitary TB was present only in one patient (P8). We were able to obtain computed tomography findings of $\mathrm{P} 1, \mathrm{P} 5, \mathrm{P} 6, \mathrm{P} 7, \mathrm{P} 8$. Radiographic imaging of the patients are presented in Figures 1-4.

ARB was observed in three (33.3\%) patients, nucleic acid amplification tests were positive in four (44.4\%) patients, and positive cultures were observed in seven $(77.7 \%)$ patients. In total, seven patients had microbiologically confirmed $(\mathrm{P} 1, \mathrm{P} 2, \mathrm{P} 3, \mathrm{P} 6, \mathrm{P} 7, \mathrm{P} 8, \mathrm{P} 9)$ and two had clinically confirmed MDRTB (P4,P5). Five patients $(55.5 \%)$ had isoniazid and rifampicin resistance, and two patients (22.2\%) had isoniazid, rifampicin, and streptomycin resistance.

\section{Patient Treatment and Outcomes}

A treatment protocol consisting of pyrazinamide, ethambutol, amikacin, protionamide, and moxifloxacin was started after evaluating the culture results of the patients and family members. Cycloserine was added to the treatment protocol of four (44.4\%) patients (P1, P2, P5, and P9). Amikacin was administered five days a week for six months.

We did not observe any side effects of amikacin. Depressive side effects and hypersomnia were observed in one patient on cycloserine (P1), and vision impairment developed in one patient on ethambutol (P2). The drugs were discontinued in each patient. All of the patients were given a high-calorie diet with protein, and vitamin D supplements were provided. Control samples including either sputum or gastric aspirate were obtained approximately one month after the first positive culture result. Complaints disappeared after an average of two months of hospitalization, and the patients were discharged
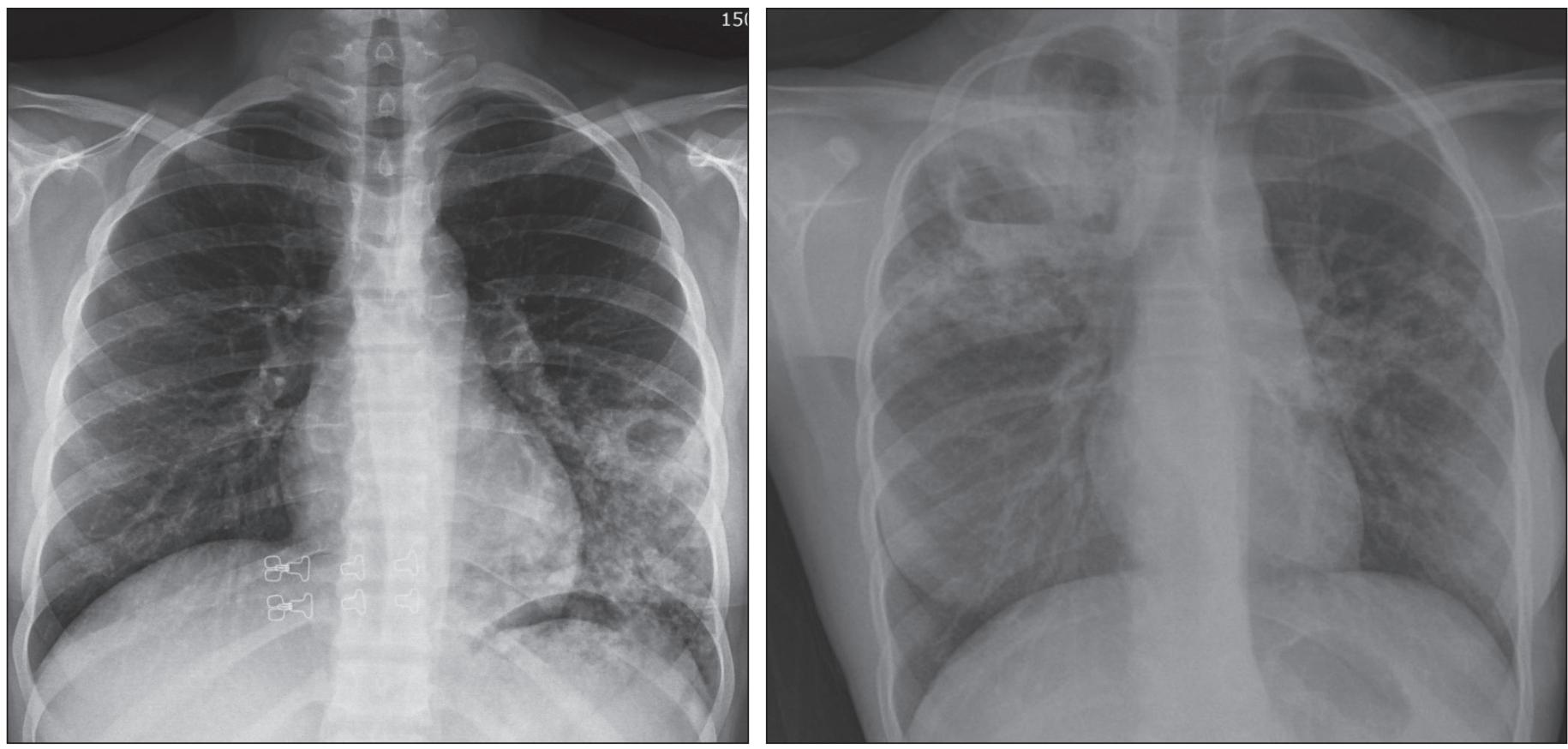

Figure 1,2. Lobar infiltration and air bronchogram in chest $\mathrm{x}$-rays of patient 3 and patient 8. 


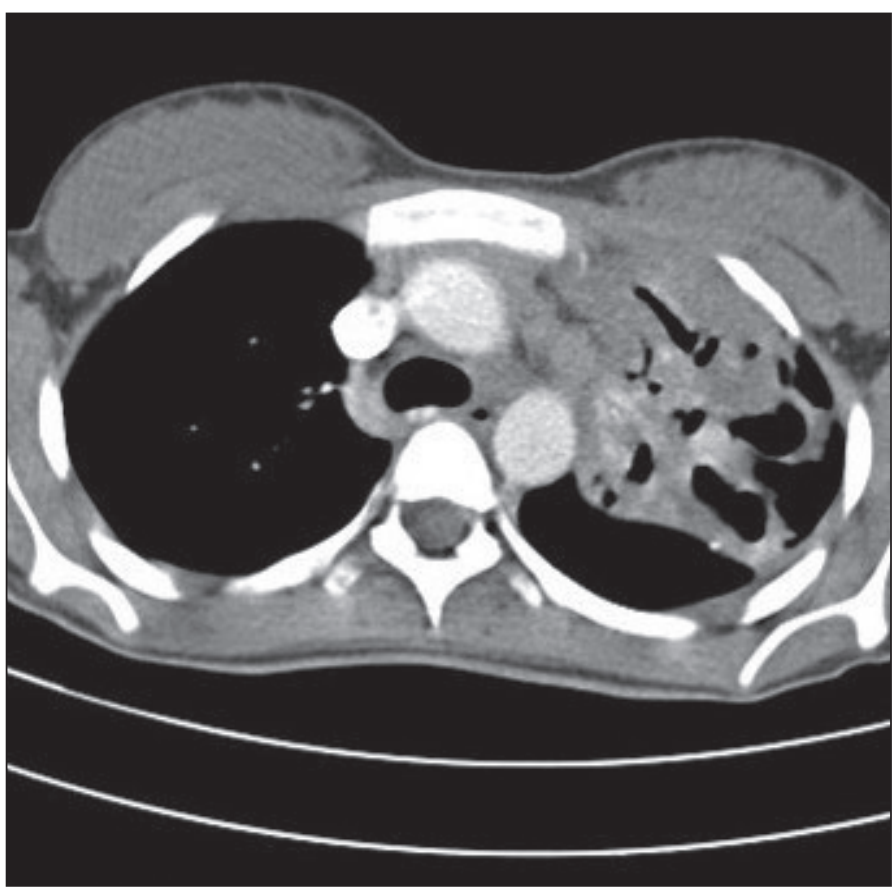

Figure 3. Mediastinal lymphadenopathy, calcification, air bronchogram.

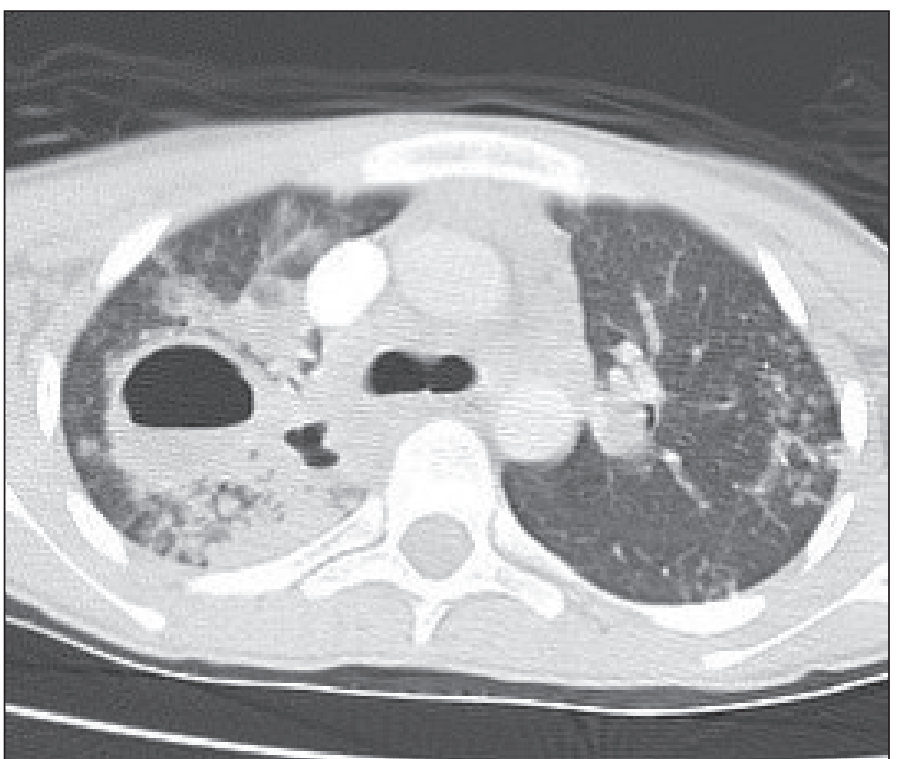

Figure 4. Cavitation in computed tomography of patient 8.

from hospital when control samples showed negative ARB and culture results and their general conditions improved. All patients were treated under direct supervision during hospitalization and ambulatory periods. The total treatment process was continued for 18 months.

The demographic, laboratory findings and treatment protocols of the patients are shown in Table 1.

\section{Discussion}

This is a single-center pediatric report about MDR-TB in Turkey. Our country has an intermediate prevalence of TB, with an incidence rate of 17 per 100.000 inhabitants (1). In 2016, 12.417 patients were diagnosed with TB, 200 of whom had MDR-TB (11). In a large pediatric study from our country consisting of 1.541 TB cases, MDR-TB has been diagnosed in $9(5.8 \%)$ patients (12). We had nine pediatric patients in total. Seven were females $(77.8 \%)$, and all were younger than 15 years. Mean age was $11.58 \pm 4.23$ years (3.75-15 years). Globally, children under 15 constitute one quarter of the cases of MDR-TB. In a large meta-analysis of MDR-TB in children, it has been found that $65 \%$ of the children were younger than 10 years, and $56 \%$ of them were females (13).

Tuberculosis is generally a disease of poor and malnourished populations. The socioeconomic and nutritional status of the patients may play an important role in the course of TB infection $(14,15)$. In this report, all of the families were of a low socioeconomic status, which is defined as families who are paid minimum wage. The body weights of all patients were below the third percentile.

Low vitamin D levels are often reported in TB cases. Vitamin D may support the induction of innate antimicrobial immune response and promote macrophage-mediated killing of M. tuberculosis $(16,17)$. Some studies suggest that vitamin D supplementation can enhance response to anti-tuberculosis therapy (18). The vitamin D levels of our patients were low and we provided supplements to each patient.

Patients living in areas with high rates of resistance, patients with unsuccessful or irregular treatment, and patients who have had close contact with infectious individuals should be evaluated for MDR-TB $(5,19)$. Investigating household contact is essential in the diagnosis of pediatric MDR-TB since the source is generally an infectious adult at home. It is necessary to have the microbiological results and the DST of the contact case. Seven of our patients (77.7\%) had family members with $\mathrm{TB}$, and five patients $(55.5 \%)$ had family members with MDRTB. Only a small percentage of the children develop MDR-TB because of inadequate treatment, non-availability of drugs, or poor adherence to treatment (20). None of these factors was present in our patients.

Management of MDR-TB patient contact is a complex process. For symptomatic contacts in whom active disease is demonstrated, a DST should be done, and appropriate treatment should be started as soon as possible. Guidelines for patients in contact with MDR-TB without active disease recommends preventive therapy, especially for patients younger than five years and for immunosuppressed patients with TST indurations of $5 \mathrm{~mm}$ or more (21). Our current guideline, reported in 2019, also recommends starting prophylaxis for patients older than five with latent TB or who are at high risk (22).

The diagnosis of MDR-TB is challenging in children due to the paucibacillary nature of the disease, difficulties in obtain- 
Table 1. The demographic, laboratory findings and treatment protocols of patients

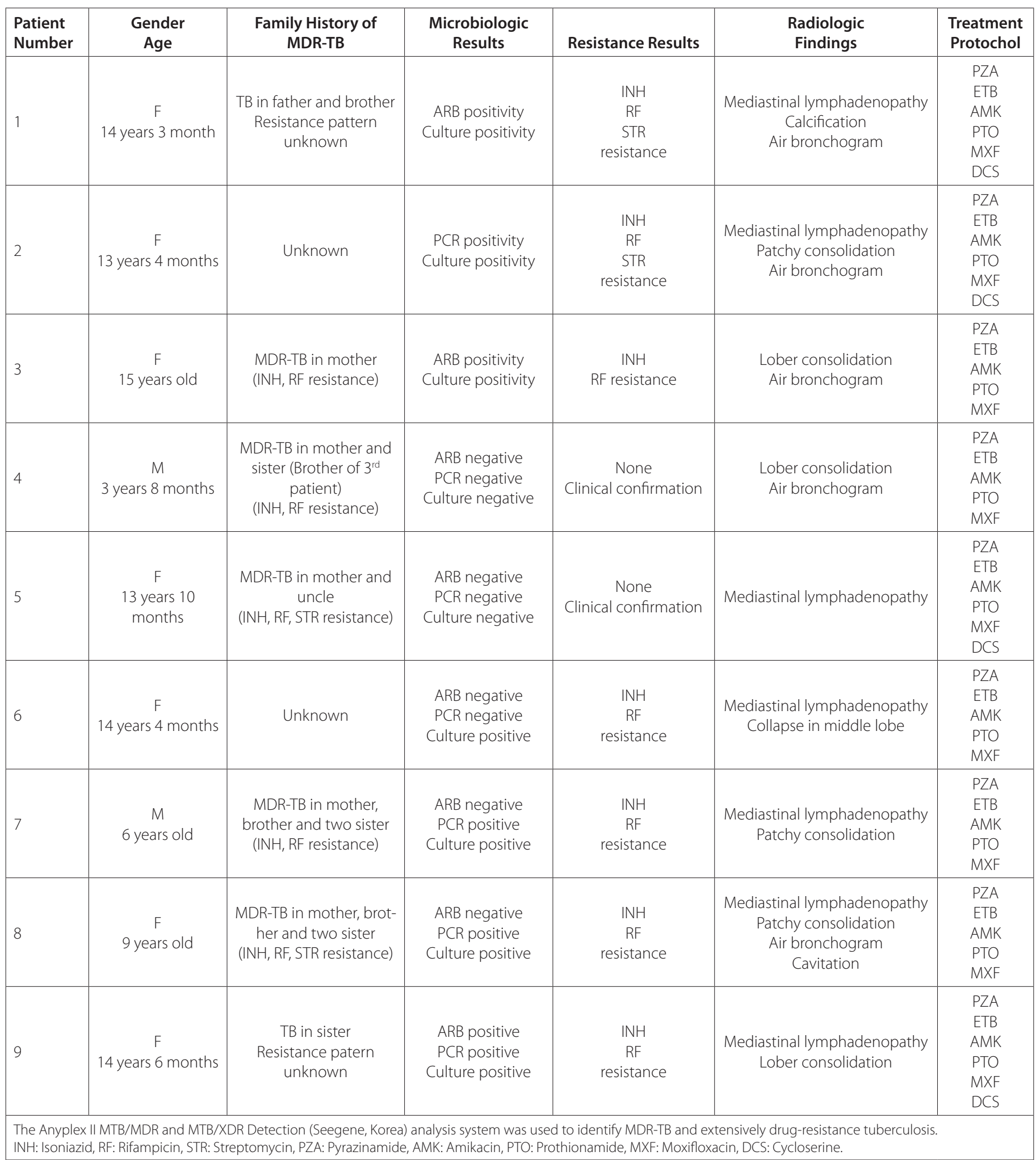

ing specimens for culture, time-consuming drug susceptibility testing, and limited laboratory capacity to conduct tests for drug resistance $(5,8)$. Children with MDR-TB are predominant- ly diagnosed based on clinical criteria without microbiological confirmation in the presence of contact with index case with MDR-TB. Patients are diagnosed with microbiologically 
confirmed MDR-TB when multi-drug resistance is determined by nucleic acid amplification tests and/or by culture in $\mathrm{M}$. tuberculosis isolates. A child with clinical TB who has a history of contact with an adult with MDR-TB but no positive M. tuberculosis culture is considered a presumed/probable MDR-TB case or a clinically confirmed MDR-TB case. A child with a history of treatment failure or who has a relapse of TB after receiving adherent first-line anti-tuberculosis treatment is considered a presumed/probable MDR-TB case (19). All of our patients were symptomatic, and we were able to perform microbiological evaluations. We did not have any cases of presumed/probable MDR-TB. Seven patients had microbiological and two had clinical confirmation of their diagnoses.

The radiological features of MDR-TB are generally similar to drug-sensitive TB. Subsegmental or lobular consolidations, centrilobular nodules, and a tree-in-bud appearance were the most frequent radiological findings in our patients. There are reports of a higher presence of cavities in MDR-TB patients, but most cases are adult patients who developed secondary resistance during or following anti-tuberculosis therapy $(23,24)$. We observed cavitary TB in only one patient.

The treatment of MDR-TB is as challenging as the diagnosis. The lack of child-friendly formulations, the higher cost of medications, the longer treatment duration, and the possible side effects of the drugs are compelling factors. The first step in treating MDR-TB is knowing the DST results of either the patient or the source case. Especially in the youngest age group ( $<5$ years), empirical treatment is based on the resistance profile of the source case. One (P4) was younger than 5 years, and the treatment regimen was designed according to the DST results of the source case. We could not microbiologically confirm two cases.

There are two treatment regimens recommended by WHO. In their latest report, the shorter MDR-TB regimen of 9 to 12 months is considered for patients who do not have a severe form of the disease, including miliary TB and central nervous system TB; who have not been previously treated with second-line drugs; and in whom resistance to fluoroquinolones and second-line injectable agents has been excluded. HIV patients with extrapulmonary disease are also not suitable for short-term treatment (25). The long-term treatment regimen is considered in children with resistance to any second-line drugs or who have previously received these drugs for more than one month, for whom the shorter MDR-TB regimen failed, and who have severe forms of extrapulmonary TB (8). The longer regimen includes at least five effective drugs, including pyrazinamide and four second-line drugs (one chosen from Group A, one from Group B, and at least two from Group C). Group A includes levofloxacin (or moxifloxacin) and gatifloxacin; Group B includes amikacin (or streptomycin), ca- preomycin, and kanamycin; Group C includes ethionamide (or protionamide), cycloserine (or terizidone), linezolid, and clofazimine $(25,26)$. High-dose isoniazid and/or ethambutol is also recommended to strengthen the regimen.

We did not have any cases with extrapulmonary TB, and we were able to test for resistance to second-line drugs. We chose the long-term treatment regimen according to the guidelines of the Ministry of Health (21). The treatment protocol, consisting of pyrazinamide, ethambutol, amikacin, protionamide, and moxifloxacin, was started after evaluating the culture results of patients and family members. Cycloserine was added to the treatment protocol of three patients due to protionamide resistance in the source case or the patient herself ( $\mathrm{P} 1, \mathrm{P} 5, \mathrm{P} 9)$. One patient $(\mathrm{P} 2)$ received cycloserine due to vision impairment while on ethambutol treatment. Another patient (P1) developed adverse neuropsychiatric reactions to cycloserine, which is a well-known side effect (27). Although second-line injectable agents are associated with an increase in successful treatment of TB, they can result in hearing loss, which has been previously reported in $24 \%$ of children treated for MDR-TB (28). We carefully followed our patients during amikacin treatment, and none of our patients developed hearing loss.

MDR-TB has a good prognosis in pediatric patients if properly treated. Treatment of MDR-TB was completed as recommended by national policy without evidence of failure, and three or more consecutive cultures taken at least 30 days apart were negative after the intensive phase of treatment (13). The success rate of MDR-TB treatment in children is generally $77.2-82 \%(29,30)$. All patients were treated successfully under supervision without loss or discontinuation of therapy in our study. However, we had very few patients compared to previous reports. In addition, we did not have cases with HIV or extrapulmonary $\mathrm{TB}$, which are independent risk factors in treatment failure (30).

In conclusion, we focused on the diagnosis and treatment of MDR-TB in nine pediatric patients. Although we had a very small number of patients, we considered it necessary to report our clinical experience because of the limited number of pediatric reports on the subject. Management of childhood MDR-TB is a long and difficult process, but it is a preventable and treatable disease. Patients with TB and a history of adult contact or treatment failure should be evaluated for MDR-TB.

Ethics Committe Approval: The ethical approval for this study was obtained from Health Science University Kanuni Sultan Suleyman Training and Research Hospital Clinical Research Ethics Committee (Decision no: 2019/05/128, Date: 11.06.2019).

Informed Consent: Patient's parent consent was obtained. 
Peer-review: Externally peer-reviewed.

Author Contributions: Concept - DA, RŞ; Design - DA; Supervision RŞ, AB, ZK; Resource - DA, TY, ÖBÖ; Data Collection and/or Processing - DA, ST; Analysis and/or Interpretation - DA, RŞ, AB, ZK; Literature Search - DA, TY, ÖBÖ; Writing - DA; Critical Review - RŞ, AB, ZK.

Conflict of Interest: The authors declare no conflict of interest relevant to this article.

Financial Disclosure: The authors declared that this study has received no financial support.

\section{References}

1. World Health Organization (WHO). Global tuberculosis report 2018. Available from: https://apps.who.int/iris/handle/10665/274453. [CrossRef]

2. Fry S, Barnabas S, Cotton MF. Update on trends in childhood tuberculosis. Curr Opin Pediatr 2018;30:152-60. [CrossRef]

3. Lamb GS, Starke JR. Tuberculosis in infants and children. Microbiol Spectr 2017;5(2). [CrossRef]

4. Hamzaoui A. Childhood tuberculosis. Rev Pneumol Clin 2015;71:16880. [CrossRef]

5. Jenkins HE, Tolman AW, Yuen CM, Parr JB, Keshavjee S, Pe'rez-Ve'lez $C M$, et al. Incidence of multidrug-resistant tuberculosis disease in children: systematic review and global estimates. Lancet 2014;383:1572-9. [CrossRef]

6. World Health Organization (WHO). Global tuberculosis report 2019. [CrossRef]

7. Yuen $C M$, Rodriguez CA, Keshavjee S, Becerra MC. Map the gap: missing children with drug-resistant tuberculosis. Public Health Action 2015;5:45-58. [CrossRef]

8. Schaaf HS. Diagnosis and management of multidrug-resistant tuberculosis in children: a practical approach. Indian J Pediatr 2019;86:71724. [CrossRef]

9. Seddon JA, Hesseling AC, Godfrey-Faussett P, Schaaf HS. High treatment success in children treated for multidrug-resistant tuberculosis: an observational cohort study. Thorax 2014;69:458-64. [CrossRef]

10. Dheda K, Chang KC, Guglielmetti L, Furin J, Schaaf HS, Chesov D, et al. Clinical management of adults and children with multidrug-resistant and extensively drug-resistant tuberculosis. Clin Microbiol Infect 2017;23:131-40. [CrossRef]

11. T.C. Sağlık Bakanlığı. Türkiye'de Verem Savaşı 2017 Raporu. Available from: https://hsgm.saglik.gov.tr/depo/...savas.../Turkiyede_Verem_ Savasi_2017_Raporu.pdf113 [CrossRef]

12. Cakir E, Erdem E, Ozlu N, Seber E, Gencer S, Kilicaslan Z. Demographic and microbial characteristics and drug resistance of childhood tuberculosis in Istanbul: analysis of 1,541 cases. J Infect Dev Ctries 2014;8:3049. [CrossRef]

13. Harausz EP, Garcia-Prats AJ, Law S, Schaaf HS, Kredo T, Seddon JA, et al. Treatment and outcomes in children with multidrug-resistant tuberculosis: A systematic review and individual patient data meta-analysis. PLoS Med 2018;15:e1002591. [CrossRef]
14. Martin SJ, Sabina EP. Malnutrition and associated disorders in tuberculosis and its therapy. J Diet Suppl 2018;29:1-9. [CrossRef]

15. Frediani JK, Sanikidze E, Kipiani M, Tukvadze N, Hebbar G, Ramakrishnan $U$, et al. Macronutrient intake and body composition changes during anti-tuberculosis therapy in adults. Clin Nutr 2016;35:205-12. [CrossRef]

16. Bruns $H$, Stenger $S$. New insights into the interaction of Mycobacterium tuberculosis and human macrophages. Future Microbiol 2014;9:32741. [CrossRef]

17. Coussens AK, Martineau AR, Wilkinson RJ. anti-Inflammatory and antimicrobial actions of vitamin $D$ in combating TB/HIV. Scientifica 2014;2014:903680. [CrossRef]

18. Wu HX, Xiong XF, Zhu M, Wei J, Zhuo KQ, Cheng DY. Effects of vitamin D supplementation on the outcomes of patients with pulmonary tuberculosis: A systematic review and meta-analysis. BMC Pulmonary Medicine 2018;18:108. [CrossRef]

19. Schaaf HS, Marais BJ, Hesseling AC, Brittle W, Donald PR. Surveillance of antituberculosis drug resistance amongst children from the Western Cape Province of South Africa-an upward trend. Am J Public Health 2009;99:1486-90. [CrossRef]

20. 20. Schaaf HS, Gie RP, Beyers N, Sirgel FA, de Klerk PJ, Donald PR. Primary drug-resistant tuberculosis in children. Int J Tuberc Lung Dis 2000;4:1149-55. [CrossRef]

21. T.C. Sağlık Bakanlığı. Tüberküloz tanıve tedavi rehberi, 2011. [CrossRef]

22. T.C. Sağık Bakanlığı. Tüberküloz tanı ve tedavi rehberi, 2019. [CrossRef]

23. Chung MJ, Lee KS, Koh WJ, Kim TS, Kang EY, Kim SM, et al. Drug-sensitive tuberculosis, multidrugresistant tuberculosis, and nontuberculous mycobacterial pulmonary disease in nonAIDS adults: comparisons of thin-section CT findings. Eur Radiol 2006;16:1934-41. [CrossRef]

24. Kim HC, Goo JM, Lee HJ, Park SH, Park CM, Kim TJ, et al. Multidrug-resistant tuberculosis versus drug-sensitive tuberculosis in human immunodeficiency virus-negative patients: computed tomography features. J Comput Assist Tomogr 2004;28:366-71. [CrossRef]

25. World Health Organization (WHO). WHO treatment guidelines for drug-resistant tuberculosis 2016. Available from: updateWHO/HTM/ TB/201604.[CrossRef]

26. Seddon JA, Schaaf HS, Marais BJ, McKenna L, Garcia-Prats AJ, Hesseling $A C$, et al. Time to act on injectable-free regimens for children with multidrug-resistant tuberculosis. Lancet Respir Med 2018;6:662-4. [CrossRef]

27. Zareifopoulos N, Panayiotakopoulos G. Neuropsychiatric effects of antimicrobial agents. Clin Drug Investig 2017;37:423-7. [CrossRef]

28. Seddon JA, Thee S, Jacobs K, Ebrahim A, Hesseling AC, Schaaf HS. Hearing loss in children treated for multidrug-resistant tuberculosis. J Infect 2013;66:320-9. [CrossRef]

29. Chiang SS, Starke JR, Miller AC, Cruz AT, Del Castillo H, Valdivia WJ, et al. Baseline predictors of treatment outcomes in children with multidrug-resistant tuberculosis: a retrospective cohort study. Clin Infect Dis 2016;63:1063-71. [CrossRef]

30. Seddon JA, Hesseling AC, Willemse M, Donald PR, Schaaf HS. Culture-confirmed multidrug-resistant tuberculosis in children: clinical features, treatment, and outcome. Clin Infect Dis 2012;54:157-66. [CrossRef] 